\title{
URBANIZÁCIÓ-IGAZGATÁS ÉS PÉNZÜGYI FÖDERALIZMUS
}

\author{
(Urban Management and Fiscal Federalism)
}

\author{
HORVÁTH M. TAMÁS
}

Kulcsszavak:

pénzügyiföderáció közjovak közfeladat-ellátás szolgáltatás-szervezés decentralizáció

A város fogalma az utóbbi két évtizedben relativvá vált, elsősorban a települési jogállások alakitásának politikája nyomán. Az urbanizált igazgatás ezért független a közigazgatási státusztól. A helyi önkormányzatokról szóló törvény hazánkban ugyanakkor a települések, kisebb mértékben a megyék választott és hivatali szerveinek múködésére épiti a szabályozás struktúráját. Ez jó volt, amikor intézményeket kellett épiteni a semmiböl, de a változatlanság nem feltétlenül erény, ha a környezet alapvető módon átalakult. A pénzügyi föderalizmus ezzel szemben a rendszer elemei közötti interakciókat állitja a leírás és magyarázat középpontjába.

Az önkormányzatok alapjogi logikájú felfogása többé-kevésbé biztos alap a mai folyamatok értelmezéséhez, azonban korántsem elegendő. Az államháztartási funkciók érvényesitésének elötérbe kerülésével párhuzamosan az önkormányzati alrendszert is inkább mozgásban, mint statikusan kell értelmezni. Vagyis ne alapegységekben, hanem funkcióegységekben gondolkodjunk. Ezek lehetnek a városias, urbanizációs funkciók, amelyeket pedig elsősorban nem feladattelepitéssel, hanem közvetett szabályozással kell megteremteni, vagy inkább ösztönözni. A demokratikus elemek ebben az összefüggésrendszerben nem választhatók el a hatékonyság és még inkább a társadalmi eredményesség (területi) szempontjaitól. Azaz, más nagy elosztási rendszerek összehangolt alakitásától.

\section{Bevezetés}

Szokták mondani, hogy a közigazgatás erőforrásait nem szervezeti keretekhez vagy szervezeti egységekhez kell hozzárendelni, hanem a ténylegesen ellátandó feladatokhoz. A városias (urbanizációs) funkciók teljesítésének már csak emiatt is sokkal inkább funkcionális egységek alapul vételével kellene történnie, mint sem mechanikusan intézményi keretek mentén. A feladatok területi alapú megosztása mégis jóval ritkább, talán azért, mert ez sem valami időtől és tértöl független adottság, hanem valójában allokációs társadalmi döntések függvénye. A funkciók meghatározásakor döntő, hogy a közszektor szerepeit milyen szủken vagy tágan vonják meg. A pénzügyi szabályozás ${ }^{1}$ ehhez képest sokszor szereptévesztésben van, amikor költségvetési politika címén át akarja venni ezt a lényegi szerepkört is. A pénzügyi föderalizmus ${ }^{2}$ elméleti kerete az, amely a kormányzati szintek között igazolja az ilyen gyakorlat tartalmatlanságát. Eszerint az urbanizáció-igazgatás feladattelepítési döntéseit jóval tágabb összefüggések figyelembevételével és stratégiai ciklus időtávjára kell meghozni.

A társadalmilag közös feladatok ellátásának egy része területi szervezésben történik. Amennyiben ez tudatos dỏntés eredménye, akkor az elrendezés létjogosultsá- 
gát, kiterjedését és gazdasági indokait leginkább a pénzügyi föderalizmus elméleti keretében szokták leírni, illetve meghatározni. A tudatosság a gazdaságtani logikában azonban nem az intézményi keretek, amilyen a település, a tagállam ${ }^{3}$ vagy a nemzeti szint önkényes kijelölését jelenti. Sokkal inkább a felismerést azon körülményt illetően, hogy a köz- és vegyes javak, valamint a közszolgáltatások előállitásának keretei területileg miképpen differenciáltak. Lehetséges tehát, hogy az intézményi keretek (például a politikai önkormányzat alapegységeinek egy része) és a közjólét szervezési szintjei valójában nem esnek egybe. Amikor így van, mi a válasz a problémára a pénzügyi szabályozás elméleti környezetében ${ }^{4}$ ? Az alábbiakban először teoretikus alapvetést adunk, majd a következtetéseket megkíséreljük ezúttal elvi síkon hasznosíthatóvá tenni a magyarországi területi feladatrendszer alakítására vonatkozóan.

A kiinduló állítás az, hogy az elméleti kérdések, megállapítások alkotó módon való alkalmazására nagyon is szükség van, ha változások, illetve megtakarítások szüksége merül fel a közfunkciók finanszírozását illetően. Másfelöl, a forrásszabályozás rendszere célszerủen sohasem választható el a feladatellátás telepítésének kérdéseitől ${ }^{5}$. Azaz csak és kizárólag fiskális természetủ rendelkezések útján nem lehet allokációs elhatározásokat eredményesen érvényre juttatni, ha még oly szabályozó karakterü is az alkalmazott eszközrendszer.

A pénzügyi fỏderalizmus elméletét eredetileg a fỏderális államszerkezetü országokra alkalmazva dolgozták ki. Tartalmát tekintve azonban a teória jelentősége jóval univerzálisabb. Valójában a kormányzatok közötti horizontális verseny és az ezzel összefüggő vertikális kapcsolatok müködésének szabályszerüségeit modellezték. Alapvetően a következő kormányzati viszonylatok természetére nézve irányadó az elmélet:

- tagállami kapcsolatok a nagy föderációkban (pl. USA),

- kormányzati igazgatási szintek közötti (decentralizációs) viszonyok,

- nemzeti kormányzatok közötti gazdasági kapcsolatok,

- a nemzetközi, transznacionális integrációk (pl. Európai Unió) gazdaságtana.

A fentiek közül univerzális a decentralizáció, valamint a nemzetközi integrációk ${ }^{6}$ problémaköre. Különösen ezek indokolják, hogy az eredetileg az amerikai föderáció belső gazdasági múködésére kidolgozott elmélet miért is kaphatott annyira nagy jelentőséget. Azaz a modell hogyan nyerhetett oly elementárisan kiterjedt érvényességet.

A továbbiakban a pénzügyi föderalizmusnak csak a decentralizációra vonatkoztatásával foglalkozunk? . Ennek alapja a T.O.M.-modell, Tiebout, Oates és Musgrave teóriáira utaló rövidítéssel. Közulük, rendszertani okból, R. Musgrave tanait érdemes elörevenni.

A tágabb elméleti összefüggésbe ágyazott kiindulópontot $R$. Musgrave először 1959-ben megjelentetett közpénzügyi teóriája jelenti (Musgrave R. 1959; Musgrave R.Musgrave, $P$. 1989), ahol a közszektor szerepét értelmezve meghatározza az államháztartási funkciókat. Az azóta klasszikusnak számító elhatárolás stabilizációs, allokációs és redisztribúciós szerepköröket különböztet meg, mint alapvetőket. 
A decentralizációs szempontot alapul véve ebből a logikából az világlik ki, hogy a különböző kormányzati (tagállami) egységek gazdasági értelemben egymással interaktív viszonyban vannak. Különbözö közszolgáltatási preferenciákat fogalmaznak meg, és ezzel összefüggésben álló adószinteket állítanak be.

Az ebbe az elméleti keretbe illesztett decentralizációs szerep közvetlen modellezését Ch. Tiebout már korábban elvégezte (Tiebout 1956). Mobilitási hipotézise szerint az emberek ideális esetben választanak a különbözö kormányzatok (városok) által fölkínált szolgáltatások és a helyi adóteher összefüggésében, hol tudják kedvezőbben kielégíteni közösségi szükségleteiket. A modell szerint odaköltöznek, ahol a feltételek összességében nekik kedvezőbbek, azaz a „lábukkal szavaznak” (Horváth M. 2002, 41-45). Ez azonban természetesen nem mindig és nem mindenkinek lehetősége, mert az abszolút és relatív tranzakciós költségek nagyon magasak lehetnek. A tiebout-i absztrakció nagyon termékenynek bizonyult. A szerzőnél elvezetett a decentralizáció tisztán gazdasági elméletének megfogalmazásához (Tiebout 1961). A konkretizálások elvégzése, illetve az absztrakció vitatása, kiegészítése pedig hosszú évtizedekre témát adott a tárgyban kutatásokat végzők széles körének.

W. Oates határozta meg államháztartási allokációs funkcióként a decentralizációt. $\mathrm{Az}$ állami feladattelepítés alapját a közösségi jólét hasznai és költségei oldaláról közelítette meg. Eszerint a közjavaknak van helyi fajtája, mivel vannak lokálisan biztosított közösségi javak és szolgáltatások, amelyek iránt a kereslet területileg eltérö. Éppen ezért az együttes jólétet növeli ezeknek a helyi és nem központi meghatározása, különben felesleges előállitás, illetve másutt hiányok lépnének fel (Szalai 2002, 425). A decentralizáció „közgazdaságtana” útján ez egyben a közfunkciók tatalmára, illetve gyakorlásuk optimális kereteire nézve jelenthetett eligazitást (Oates 1972; Lockwood 2006). Oates decentralizációs teorémája lehetővé tette a közfeladatok telepítésének modellezését, végső soron az összehasonlító számszerüsités logikai keretét is kijelölve. Arra vonatkozóan, hogy ez mennyire nem csupán kvantifikáció, M. Olson költségvetési ekvivalencia elvét érdemes még felidézni. Eszerint a közfeladat-ellátási felelősség jellege azonos a nagy és erős egységek, illetve a kicsi és csekély kapacitású helyhatóságok tekintetében (Olson 1969).

Összességében a T.O.M.-modell a következő előfeltevéseken alapul (Dafflon 2006, 275):

- vannak tiszta helyi közjavak,

- az adófizetés és a közjavakból (közszolgáltatásokból) való részesedés között direkt egyenes arányú ősszefïggés van,

- teljes a mobilitás, továbbá

- nincsenek túlcsordulási hatások (1. erre még: Batina-Toshihiro 2005, 310).

$\mathrm{Az}$ ilyen módon, tehát a gazdaságtanilag értelmezett pénzügyi fơderalizmus kormányzati szerepek közötti elhelyezése, értelmezése, annak pontosítása vagy egyes elemeinek vitatása az elmélet fejlődésének megannyi állomását képezte később. A kiinduló absztrakció, a modellalkotás mindenesetre nagyon termékenynek bizonyult. Az egyes előfeltevések feloldásakor a teória alapján hozzárendelhető eszközrendszer kezelhetö a gyakorlatban. 


\section{Decentralizáción keresztül érvényesülö államháztartási funkciók}

Musgrave teóriájából kiindulva a kormányzat allokációs, újraelosztó és stabilizációs funkcióját különböztetik meg. Kezdetben uralkodó volt az az álláspont, miszerint a helyi kormányzatra ezek közül mindenekelőtt az allokációs funkció realizálásában való részvétel hárul, mivel a stabilizáció és az újraelosztás alapvetően központi feladat. Ezt a hozzáállást már a modellegyszerủsités logikája is sugallja. Aztán a figyelem arra irányult, hogy a többi funkció összefüggésében is feltárják a decentralizáció pénzügyi jelentőségét és korlátait. Így a stabilizációs funkcióra nagyon is hatással lehet a területi költekezés vagy annak korlátozása (1. ennek összefoglalására Szalai 2002, 430-431). A redisztribúció csak a pénzügyi föderalizmus logikájában mozogva maradhat intakt a helyi szintektől. Más felfogások és irányzatok éppen a társadalmi döntéshozatal áthatásaira hívják fel a figyelmet. Mindebből gondolatmenetünknek ezen a pontján annyi fontos, hogy a szintek által gyakorolt szerepeken túl a központi kormányzat önkormányzat-politikáját is érdemes a vizsgálódás körébe vonni. Nem csak allokációs logika alapján tanácsos elemezni például a forráselosztás müködését.

Ugyancsak kérdésessé tehető a funkciók éppen ilyen elhatárolása és nevesítése. Az ezzel kapcsolatos irodalom taglalására nem térünk ki. Egy fontos kiegészítés azonban idekívánkozik. A témánk szempontjából fontos alapokat tárgyalva Bailey hozzáteszi a fentiekhez még a regulációs szerepet (Bailey 1999, 6). A regulációs funkció olyan mértékben helyi, amint azt a közfeladatok ellátásának megszervezésében való szerepek központi kormányzati szinttel való megosztása, azaz a feladatátadás mértéke indokolja (Bailey 1999,6).

a) A pénzügyi decentralizáció (Péteri 1992; Szalai 2002) szerint azonban alapvetỏen az allokációs szempont alapján határozható meg, hogy a gazdaságilag hatékony társadalmi múködéshez mely piaci kudarcok kiküszöbölése szükséges; márpedig ezek jó része különböző területi szinteken kezelhető (Oates 1972; King 1984). Adódik tehát a kérdés: mennyiben helyi szintü a piacgazdaságban az allokációs funkció? Tekintve, hogy az allokáció a piaci viszonyokhoz képest a közszektor kiterjedésének és szerepeinek meghatározásában fejeződik ki, a kérdés így is átfogalmazható: a verseny fenntartását célzó beavatkozások mely piaci kudarcok esetén követelnek decentralizált beavatkozást?

A közjavak közül nem egyet önkormányzatok biztosítanak, amilyen például a közvilágítás, a közparkok fenntartása. A természetes monopóliumok közül számos a helyi közfeladatok teljesítésével áll összefüggésben, ilyen az ivóvíz-ellátás, a közcsatornázás. Az oktatás, a szociális ellátás alap-, illetve középfokon meritórikus javaknak, illetve bizonyos értelemben externáliáknak számítanak, amire is tekintettel a kormányzat különböző szinteken teljesíti társadalmi kötelezettségeit. Ez bizonyos tartalom erejéig ingyenességet vagy kedvezményeket jelent, de mindenekelött, ha a szolgáltatást magánintézmények biztosítják is, a rendelkezésre állás garantálását értjük alatta. 
Valójában helyi szinten kezelendő a külső gazdasági hatások (externáliảk) bizonyos része. Mielött továbblépnénk, nézzünk erre egy jellemző esetkört. A környezetvédelem egyes területei például lokális feladatként kerülnek meghatározásra. A magyar szabályozás szerint ilyen a káros zajkibocsátás elleni védelem egy része, illetve az épített környezet védelme. A piac magától nem kezelné az ezzel kapcsolatos konfliktusokat, hiszen a szereplöknek egyenként ez vissza nem térülö többletköltség volna. Ha viszont senki sem fordít rájuk gondot, előbb-utóbb mindnyájuk haszna csökken. A kormányzati szerep létjogosultságát ez az önszabályozási kudarc-képlet okozza. Több vonatkozásban a közszerepeket az optimális hatás érdekében a megfelelő közösségi szervezési keretek között kell biztosítani.

A decentralizáció szintjei szempontjából az externáliák egy bizonyos típusának van jelentósége. A külső hatások gazdasági szerepe sokszor áttételes ${ }^{8}$. Máskor a külső hatások érvényesülése területileg elhatárolható, akár kedvezőtlen, akár kedvezö következményekröl van szó. A decentralizált feladatellátás szempontjából ezeknek a területi externáliáknak van jelentösége. Ugyan nem minden területi externália kezelése közszektorbeli, még kevésbé közigazgatási probléma ${ }^{9}$, azért amennyiben igen, a piaci kudarcok közül a területi externáliáknak a jelentőségét illetően a kormányzati kezelés szintje meghatározásának fontosságát kell kiemelni. Itt ugyanis nemcsak az a lényeges, hogy a közfeladat ellátása nem feltétlenül központi, hanem ha helyi, akkor a megszervezés milyen szinten történik: települési, térségi, megyei, avagy regionális keretek között; illetve, ha települési szinten, milyen méretkategóriára, településnagyságra vetítve. Egy városi gimnázium és még inkább annak kollégiuma esetében a beiskolázás nyilvánvalóan túlterjed a településen. Az ún. túlcsordulási hatás pozitív externáliaként jelentkezik a környéken. Klasszikusan negatív külső hatás viszont a környezeti következmények léte, például az élővizek szennyezése a települési folyékony hulladék által.

A kormányzati kezelés válaszul a piaci hatások externális következményeire többféle lehet. Az egyik szokásos válasz a külső hatások belsővé tétele, az internalizálás. Maradjunk most itt is a területi externáliák kezelésének körében ${ }^{10}$. Ebben az esetben olyan szabályozási szituációt kell találni, amelynek keretei között pozitív és negatív hatások egyaránt kifejtik szerepüket, például szolgáltatási (mondjuk, beiskolázási) körzet meghatározásával, vagy azzal, hogy a támogatással követik az igénylót; a csatornázás esetében a tisztítómủ támogatásának térségi vagy központi kezelésével. Az internalizálás mechanikusabb változata a méretgazdaságosság elvének az alkalmazása. Eszerint a mértékadó kapacitások mentén telepítik a feladatköröket. A kollégiumi példában az intézmény nem a székhely szerinti városhoz kerül, hanem ahhoz a területi egységhez, mondjuk a megyéhez, amely szint által nagyjából lefedhető az igénybevevők hovatartozási köre. Az internalizálás komplexebb értelme nem szakítja el a területi egységek definiálását az alapvetö összefüggés köréböl. Ami nem más, mint hogy a helyi önkormányzatok feladatellátási körének, illetve az abban foglalt tartalmaknak a meghatározása nem szimpla beavatkozás, hanem a piaci kudarcok kezelésének adott technikája. Ekkor 
az internalizálás komplexebb megoldási eszköztár, amelyiknek legfeljebb része a szintek igazgatásszervezési kialakítása.

b) A pénzügyi decentralizáció az allokáció egyik alcsoportján kívül, mint említettük, tágabb értelemben még más funkciókon belül is megjelenik. Többek között szabályozáspolitikát is jelent, ami bizonyos értelemben a redisztribúció körébe vonható, például minimális szolgáltatási szinteket határoznak meg, vagy bevételkiegyenlítést alkalmaznak. Az ilyen döntések meghozatalát szúklátókörüség lenne csak allokációs tartalmában kötni a szintekhez, mikor valójában a döntés meghozatala, a preferenciák elfogadása nagyon is kapcsolódik a helyi pozíciókhoz. A pénzügyi decentralizáció teóriájának alkalmazásába ma már ez is belefér, különösen akkor, ha más elméletekkel való kapcsolatban is gondolkodunk. (Jelen esetben ilyenek a közösségi döntések elméletei.) Mint már utaltunk rá, a kormányzat államháztartási funkcióinak allokáción kívüli többi területe is kisebb-nagyobb mértékben a különböző decentralizációs szinteken érvényesül.

Az allokációs szerep elsődlegessége azért jelentős még mindig, mert így a feladatoldal, a területi szerepkörök társadalmi rendeltetése kerül elötérbe. Ugyanakkor a források szempontja természetesen ugyanolyan fontos. A forrásmegosztás vonatkozásában a pénzügyi föderalizmus tételei szintén fontosak. Söt, a gyakorlatban még inkább ez az elméleti terület kerül alkalmazásra. Ez önmagában nem hiba, csak akkor, ha elszakad a forrásmegosztás elméleti feltételrendszere a közfeladat-ellátás politikai gazdaságtani követelményeitöl. Ebben az esetben ugyanis a pénzügyi föderalizmusnak csak a technikái kerülnek alkalmazásra. Például: milyen támogatástípust alkalmazzanak, hogyan férjenek bele a rendelkezésre álló forráskeretbe? Márpedig a piacgazdaság közfeladatainak területi szinten való értelmezése nélkül a forrásszerkezet fejlesztése érdemben és hosszabb távra, társadalmilag eredményesen aligha képzelhető el.

A regulációs funkció alatt a piacgazdaságban szokásos szabályozó szerepet kell érteni, tekintet nélkül annak megvalósulási formájára, ami természetesen nem feltétlenül jogi formájú. Ha azonban az, akkor sem szakitható el a rendelkezésre álló eszközrendszer többi elemétöl. A megvalósítás alapvetően központi szervezésü, hiszen a piacot nem célszerü indokolatlanul fölparcellázni. Ugyanakkor meghatározott pontokon a szinteknek lehet szerepe. Példaként említhetjük a célorientált és többszintü árszabályozást meghatározott közszolgáltatások tekintetében; vagy a fogyasztóvédelmet.

A kormányzat stabilizációs funkciójának érvényesítése pedig értelemszerủen a decentralizációra is kihat, alkalmasint nagyon is. Így például a deficit-finanszírozás kérdése, amely nehéz költségvetési helyzetben erősen korlátozó lehet a többi funkció alkalmazásának mértékére és módjára nézve.

A funkciók mindezen sokoldalú kapcsolódása miatt a továbbiakban a pénzügyi decentralizáció allokációs funkcióra rendeltségét kitágítjuk. Általában véve úgy, miként a modern megközelítések többsége teszi. Ugyanakkor a közösségi szerepek területi meghatározásának fontosságát igyekszünk kiemelten figyelembe venni. Ennek az elsödlegessége esszenciális, többek között a pénzügyi szabályozás koncepciója szempontjából is. A funkciók egymásra hatását tehát az allokációs szerep helyi érvényesülésének alapján kell vizsgálni a továbbiak során. 


\section{A modell egyes egyszerüsitéseinek értékelése}

A pénzügyi föderalizmus alapmodelljében az elöbbiek szerint kulcsszerepe van a helyi közjavak sajátlagos termelésének. Ebbỏl következően a valóságban sokszor oly fontos kiegyenlítés funkciója nem áll előtérben, csak korrekcióképpen kezelhető. Ez persze nem feltétlenül rossz dolog, hiszen a közszektor „reálfolyamataitól” való elszakadás terjedelmét már önmagában, megközelítésmódjával korlátozza.

Eredetileg a koncepció kifejezetten gazdaságtani. A pénzügyi föderalizmus széles körủ irodalma azonban szabályozáspolitika, döntési, szolgáltatásszervezési és területpolitikai kérdésekre egyaránt kiterjed (1. és vö. Dafflon [2006, 293-298] értelmezésével!) Ennek jogosságát mutatja, hogy a feladattelepítés a kormányzati szintek között valójában sohasem tiszta. Egyes vonatkozásokban központi a döntés, más tekintetben tartományi vagy regionális, megint más összefüggésben és konkrét tartalommal helyi vagy települési. Ekkor a pénzügyi decentralizáció magyarázó elméletként szerepel legfeljebb. Ezek a kapcsolatok bár rontják a tiszta elméleti konzisztenciát, de egyben az alkalmazhatóság köreit társadalomtudományi értelemben jelentősen kiterjesztik.

$\mathrm{Az}$ alapmodell alapvetően normatív elmélet. A pénzügyi föderalizmus egésze azonban természetszerüleg pozitív, leíró irányokat is tartalmaz. Eszerint a közfeladatok ellátásának feltételeit, kereteit kell vizsgálni olyan rendszerben, amely megfelel az alapvetéseknek, illetve a megfelelöképpen konkretizált további változatainak. Nemcsak szabályozási javaslatokat lehet tehát a gyakorlatban megfogalmazni, hanem a müködési tapasztalatok rendszerezésére is felhasználható az elmélet.

Érdekes kérdés, hogy vajon nem csak a nyugati fejlődés fősodrára alkalmazható-e ez az egész? Első pillantásra nagyon úgy néz ki, hiszen tiszta piacgazdaságot másutt, mint Észak-Amerikában és Nyugat-Európában történetileg vagy akár analitikusan még csak tételezni sem lehet. ${ }^{11}$ Például végképp értelmezhetetlennek túnik a mobilitási hipotézis az életszínvonal eltérése miatt, vagy tradicionális okokból. A bürokrácia szerepe egészen más, adott esetben rendszeralkotó, de egészen másképpen. Ha léteznek is a nyugati mintának megfelelö struktúrák, például a polgári önkormányzatok, azok alkalmasint fejletlenek, és ez egyáltalán nem véletlen. Bardhan (2006) számos ilyen és hasonló tényezőt sorol fel a harmadik világ folyamatait elemezve. Hozzátehetjük, hogy az átalakuló országokra vetítve sem irreális a legtöbb felvetés, beleértve az Európai Unióhoz immár csatlakozott „leginkább” európai országokat is. Külön kiemelésre érdemes még ebben az összefüggésben a globalizáció kihívása. A pénzügyi fơderalizmus reagens a kormányzati szintek problémájára ebben az összefüggésben is, csakhogy nem feltétlenül a globális fejlődés ma már egyértelmủ feszültségei szempontjából.

A decentralizáció gazdaságtani felfogása nem érzéketlen a felvetett tényezőknek az elméletbe való beszámítására. Így a tranzakciós költségek számításba vétele régi tételei közül való. Persze egészen más a bürokratizmust egy költségtényezőnek tekinteni a sok közül, még ha nagynak is, mint ha erre épül tényleg a társadalomszervezés. További tényező a felelősségek összemérése és kontrollja különböző 
társadalmi ,játékok" útján (választások, civil kontroll, egyéb közösségi döntések). Egyes piacikudarc-fajták előfordulásának vagy hatásának korlátozása is integráns része az elméletnek, pl. az információs aszimmetria csökkentése tekintetében. Mégis, az egyáltalán nem piacgazdasági logikára szerveződött társadalmak esetében a decentralizáció és a pénzügyi decentralizáció alkalmazása kétséges lehet.

A mi esetünkben természetesen nem ez a helyzet. Az előzőekben tett közbevetések azonban rámutatnak a korrekciós tényezők figyelembe vételének fontosságára. A decentralizáció összefüggésében a kormányzati funkciókat a következőképpen nevesíthetjük: $\mathrm{Az}$ allokációs funkciónak megfelel a szintek közötti feladatmegosztás rendszere. A redisztribúció alapvetően a központi kormányzat pénzügyi szabályozáspolitikáján keresztül valósul meg. A stabilizáció decentralizációs szála a makroszabályozás meghatározott tárgya. A regulációt annak közvetlen formájában, a helyi közfeladatok tekintetében az önkormányzatok szolgáltatás-szervezési politikája valósítja meg. Kérdés most már, hogy az egyes funkciókat, azaz a piaci elégtelenségek kiküszöbölését milyen átfogó feladattípusok testesítik meg. Ezeket azért kell tisztáznunk, mert kezelésüket megfeleltetjük majd a forrásszabályozás, illetve a feladatrendszer-szabályozás pénzügyi eszköztárának.

\section{A funkciók tartalmának konkretizálása}

A decentralizáció szempontjából releváns államháztartási funkciók tartalmaznak bizonyos jellemző alfunkciókat, amelyeket a közszolgáltatási feladatok megoldása során a kormányzatok biztosítanak. Utóbbiak megosztják szerepeiket a különbözö államszervezési területi szintek között. A telepités módját és tartalmát áttekintő rendszerezésben ábrázolhatjuk. A séma tanulságai az önkormányzat-politika alakítása során hasznosithatók.

A fentiek alapján az államháztartási funkciók decentralizáció szempontjából releváns alfunkcióinak rendszeréből indulunk ki, mégpedig azok gyakorlását illetóen az államszervezet különbözỏ szintjei szerinti bontásban. Az alábbiakban ezt a teoretikus struktúrát táblázatos formában foglaljuk össze (1. táblázat). ${ }^{12}$ Szintekként elöször is a központi kormányzatot definiáljuk, ami döntési értelemben természetesen nemcsak a kormány, hanem a parlament és egyes nem kormányzati alárendeltségben lévő szervek meghatározott köre. Másodszor a regionális szintet tüntettük fel, ami alapvetően önkormányzati formájában alkalmas a jegyzett funkciók ellátására. Végül a helyi fórumok települési és megyei önkormányzatokat takarnak (a magyar önkormányzati törvény fogalomhasználata szerint), illetve a körzeti szint is ideérthetô, ha kormányzati tartalom tulajdonítható neki. Hazánkban a kistérségről egyelöre ez nem állítható, de a jövőre nézve ilyen szerepét nem lehet kizárni. 


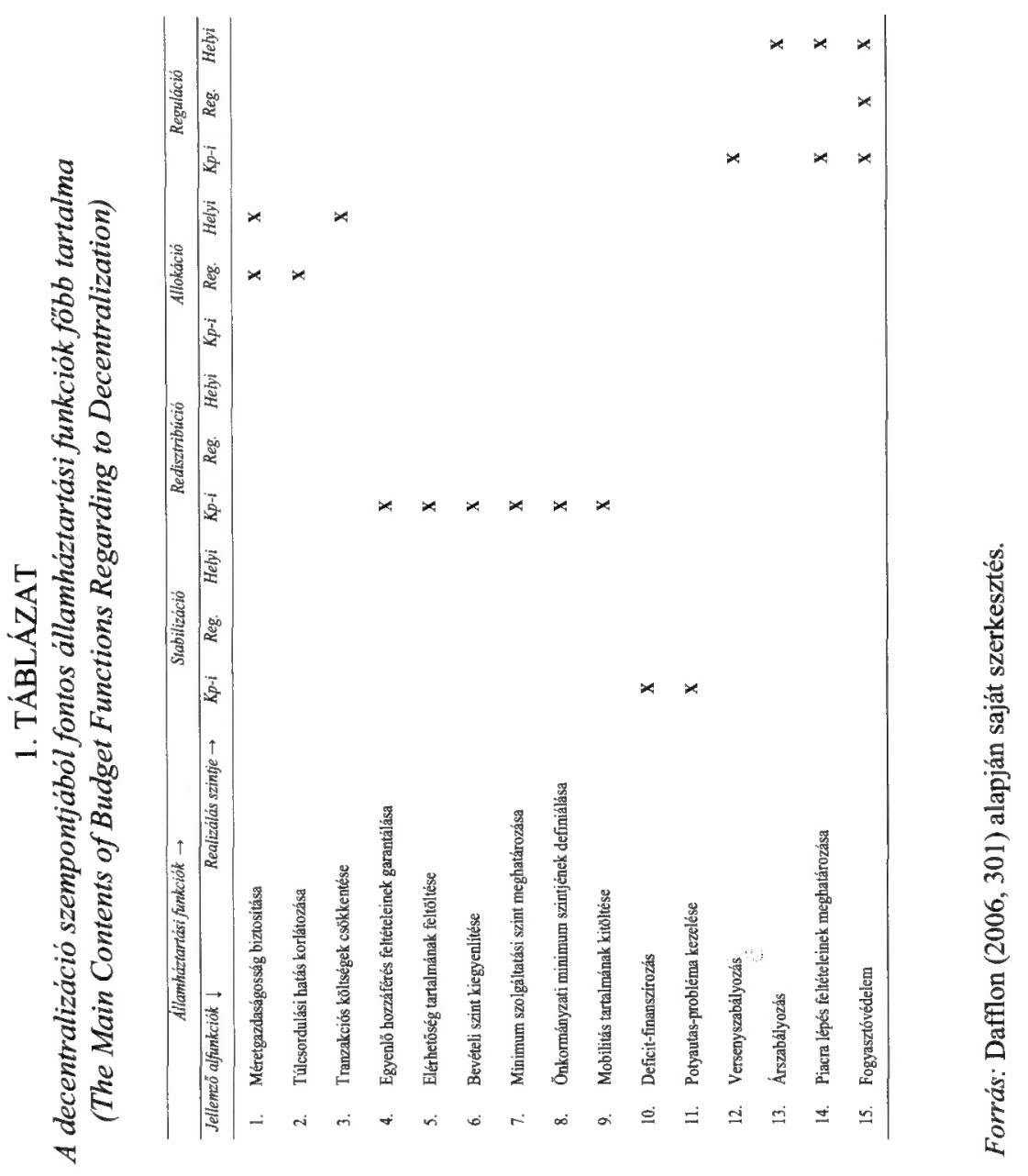


a) Az allokációról említettük, hogy a helyi közjavak, illetve klubjavak tekintetében helyi kormányzati szinten valósul meg. Értve ez utóbbi alatt a lokális (települési, illetve alapszintü) és regionális (területi, illetve térségi) intézményeket. Jellemző alfunkció itt a méretgazdaságosság biztosítása. A közszolgáltatás megszervezési egységének minél inkább igazodnia célszerủ a feladatellátás optimális szakmaitechnikai kapacitásához. A méretgazdaságosságnak különleges jelentősége van a helyi szolgáltatási természetes monopóliumok tekintetében, valamint az intézményi ellátások költséghatékony biztosításában.

Az ún. túlcsordulási (spillover) hatás beszámítása a finanszírozásba a következö szerepkör. A helyi kormányzatok nincsenek elszigetelve egymástól, az ellenkezője csupán elméleti absztrakció. Valójában egymással eredendően interaktív viszonyban vannak, legalábbis, ami a közfeladatok igénybevételét vagy a szomszédos környezeti és más hatások élvezetét vagy elszenvedését illeti. A spillover hatások a helyi közjavak és közszolgáltatások áthajlása következtében jelentkező potenciális allokációs döntéseket váltanak ki. Jellemző például a regionális vagy nagyobb területi szinten történő funkciókezelés.

A tranzakciós költségek csökkentése jellemzỏen a kormányzati kudarcok korlátozásával összefüggésben merül fel. Az igazgatási hatékonyság ellen való lehet a túlságosan szétaprózott területi kormányzati struktúra. Természetesen ezt nehéz megítélni általában. Lehetnek ugyanis más társadalmi elönyök, amelyek kompenzálják a ráfordításokat. A közfeladat-ellátással kapcsolatos tulajdoni szerkezet túlzott differenciáltsága ugyancsak költségnövelỏ lehet, ami megfelelő döntési politikával keretek között tartható.

Mint látható, a decentralizációs összefưggésủ allokációs funkciógyakorlás helyi kormányzati szinteken realizálható. Ez látszólag magától értetődő. Valójában azonban a decentralizációval kapcsolatos politika másik funkcionálisan komplex csomagját a helyes eredmény elérése érdekében központi szinten kell gyakorolni. Ez a helyzet a redisztribúciós államháztartási funkcióval.

b) A redisztribúció sokrétủ fogalom. Nekünk itt most a decentralizáció érdekében való megvalósítására kell kitérnünk. A központi szint alkalmazott politikájával különösen a következó alfunkciók realizálására törekszik: biztosítania kell a lehetöségekhez képest a helyi kőzjavakhoz és -szolgáltatásokhoz való egyenlő hozzáférést. A decentralizáció elve az egységes nemzetállamok óta az, hogy tekintet nélkül az életvitel helyétől a társadalmilag közösen szervezett szükségletkielégités útján mindenki részesedjen. Ez azonban természetesen nem jelenti azt, hogy okvetlenül helyben és azonos költségért.

A következő alfunkció az ellátás bárhonnan való elérhetősége. Azaz, reális ellentételezésért a hozzáférés joga realizálható. Ennek feltétele, hogy az elérési költségek ne legyenek irreálisan nagyok. Nemcsak pénzre kell itt gondolni, sőt, nem is arra elsösorban, hanem társadalmi költségre. Például, ha a sürgösségi ellátás az átlagos szinthez képest nagyon hosszú idő után érhető csak el, annak a költsége, az abból fakadó károk jelentősek lesznek egyéni és közösségi szempontból számba véve egyaránt. 
A bevételi szint kiegyenlítésének funkciója az egyenlőtlenségeket a helyi források kiegészítésével próbálja enyhíteni. A közjavakból és -szolgáltatásokból való részesedés korrekciójáról van szó. Erre bizonyos szintig mindig szükség van, hiszen a területi vagy települési egyenlőtlenségek irreális szinten tartása általában a társadalom egészének sem érdeke. Ugyanakkor a teljes szintrehozás kísérlete is ellenérzéseket szül. A jobb módú térségek, városok nem érdekeltek költségvetési hozzájárulásuk szintjének minden határon túl való emelésében.

Ellentétes hatású a minimum szolgáltatási szint elöírása. Ekkor a közjavak és vegyes javak biztosítója számára állapítanak meg kötelezettséget annak érdekében, hogy az ellátásszervezés rendszere ne parcellázódjon fel túlságosan. Jellemző kormányzati kudarc ebben a körben, hogy a helyhatóságok igyekeznek önellátásra berendezkedni, mert azzal befolyásuk, alkupozíciójuk a helyi közösség felé, illetve más kormányzati szintek irányába várhatóan kedvezőbb lesz. A minimum standardokkal nem feltétlenül ellentétes, de egy bizonyos, megállapodás szerinti mérettől velük szemben védelmet is jelent az „önkormányzati minimum”. Eszerint egy adott szolgáltatási szintet önkormányzati egységenként, átfogó kapacitásképpen tudni kell garantálni. Összevontabb rendszerek alapszintjei ${ }^{13}$, illetve feladatellátási paraméterhez rendelt regionális szintek ${ }^{14}$ esetében szoktak ilyet meghatározni.

Végül a mobilitás szabályozása ugyancsak a decentralizáció ösztönzésével összefüggő redisztribúciós államháztartási funkció része. A központi kormányzatnak érdeke lehet a közjavak piacának gerjesztése vagy éppenséggel korlátozása. Az előző esetben a társadalmi szintủ gazdaságosság érvényesítésének szempontja lehet mérvadó. Az utóbbi viszont az esetleges túlkereslet korlátozásaként jöhet szóba. Az egyoldalú urbanizációt követő elvándorlást például bizonyos korszakokban adminisztratív intézkedésekkel próbálták kordában tartani.

Összességében a redisztribúciós funkció decentralizációs tartalma egységes kormányzati szabályozási politika formájában bontakozhat ki. Mindez elsődlegesen pénzügyi-költségvetési eszközrendszer alkalmazását jelenti a piacgazdaságban. Látható, hogy a szabályozási politika nem maradhat magára. Területi szintủ allokáció nélkül, pusztán költségvetési eszközökkel, tartósan jótékony hatást aligha lehet elérni. Példảul a tranzakciós költségek csökkentése nélkül a szolgáltatás elvárt szintjének meghúzása ellentmondásos eredményre vezet. Széttagolt önkormányzati rendszerben történetesen ezáltal el kell vonni alapfeladatokat a települési egységektől.

c) Ha már a központi szerepeknél tartunk a decentralizáció biztosításában, akkor a stabilizációs funkció körébe esőket is vegyük számba. Közülük kiemelésre érdemes a deficit-finanszírozás, amely magában foglalja az eladósodás korlátozását, valamint az esetleges hiányok kezelését, az önkormányzati kötvénykibocsátást. Az államháztartás egyensúlyának kézbentartása érdekében szükséges az egyes alrendszerek kiadásainak kordában tartása.

A makroszintủ szabályozás körébe tartozik a potyautas-probléma kezelése. Az önkormányzatokra hasonlóképpen igaz, mint az állampolgárokra, hogy a közjavak piacán hasznaikat akként próbálják maximalizálni, hogy igyekeznek elkerülni az 
igénybevételi költségek megfizetését. Azaz a támogatásokért sorban állnak mindnyájan tekintet nélkül saját erőforrásaik nagyságára. A központi szabályozás különbözö ösztönzőkkel késztet a bevételi kapacitás kiaknázására, egyben a szükséges közösségi hozzájárulások befizetésére. A hazai pénzügyi eszközök közül különösen ilyen az adóerö-képesség szerinti szabályozás.

d) A regulációs funkció egyes elemei központilag, mások helyi szinten valósulnak meg, végül vannak olyanok, amelyek vegyesen. Ismét csak a decentralizáció érvényesítése tekintetében vesszük számba az alfunkciókat. Érdemes rámutatni, hogy ezek a szerepek, amennyiben decentralizálhatók, klasszikus szabályozási eszközökkel valósulnak meg, amilyen a gazdasági tervezés, a fejlesztési és rendezési tervezés, a helyi jogalkotás.

A versenyszabályozás teljesen központi alfunkció. A versenyfeltételeket egységesen kell biztosítani, ráadásul az adminisztrációtól jelentős részben független intézmények útján. Decentralizációs összefüggés különösen a természetes monopóliumok körébe sorolható közüzemi szolgáltatások esetében van, amelyek tekintetében a versenyszabályozás központi kormányzati szinten valósul meg.

Az árszabályozás ugyanebben a körben jellemzö, de már helyi szintü megvalósítást is feltételez. Az árképzés elfogadása meghatározott körben (nálunk pl. a helyi tömegközlekedés tarifái, távhö-dijak, víz- és csatornadíjak, szemétszállítási dij) önkormányzati hatáskörben vannak. Lévén szó természetes monopóliumokról, a közösségi szerep, beavatkozás indokolt - a verseny fenntartása érdekében.

A piacra lépés feltételeinek meghatározása megosztva központi és helyi feladat a decentralizált közösségi feladatellátás körében. Helyi hatáskör állapítható meg például a települési szilárd hulladékgyüjtés és elhelyezés szolgáltatása tekintetében.

A fogyasztóvédelem kiválóan alkalmas az információs aszimmetria csökkentésére. A funkció ráadásul klasszikusan egyre inkább társadalmasított. Ezen a ponton az önkormányzatoknak is osztanak lapot, azonban jól látható, hogy a decentralizáció nem az egyetlen lehetséges forma a központi feladatmegoldás kiegészítésére vagy éppenséggel egyensúlyozására.

\section{Konklúziók}

$\mathrm{Az}$ 1. táblázatból jól látszik, hogy a decentralizáció útján érvẻnyesülni képes redisztribúciós funkciókat központi pénzügyi szabályozás útján kell realizálni. Hozzátehetjük, tulajdonképpen ez a forrásszabályozás. A helyi és regionális szinteken biztosítható közjavak és vegyes javak allokációja ezzel szemben közvetlenül a decentralizált szinteken történik - legalábbis a polgári demokratikus rendszerek piacgazdaságaiban. A kiadási oldal társadalmi értelemben vett hatékony felhasználás irányába terelése ezért az allokációs alfunkciók decentralizált érvényesitésével valósul meg. Pénzügyi jelentősége természetesen a regulációs funkciónak is van, csakhogy az alapvetően nem a költségvetési szabályozás összefüggésében jut kife- 
jezésre. A stabilizáció vonatkozásában alkalmazott eszközök pedig az államháztartás egészének kezeléséből vezethetők le.

A helyi és regionális szerepkörök közvetlenül tehát az allokációs és a piacgazdasági értelemben szabályozó (azaz nem egyszerüen jogi normatív) funkciók egyes összefüggéseiben kerülnek elötérbe. Vagyis a kérdés nem egyszerủen a feladatok szintek közötti telepítése, sokkal inkább a köz- és a magánszektor közötti allokáció tartalma! Ma hazánkban különösen aktuális, hogy a legnagyobb, legköltségesebb feladatcsoportok tekintetében az állami szerepek általában hogyan alakulnak. Az egészségügyi ellátást illetóen viták kereszttüzében áll a közszektor pozícionálása, de összességében súlyának csökkenése valószínúsíthetö. Ugyanez a helyzet az oktatásban, és kevésbé látványosan, de a valóságban töretlenül átalakulóban van a személyes szolgáltatást nyújtó szociális ellátások terheinek allokálása. Szembe kell nézni a közfeladat-ellátás nagy rendszereiben is az önkormányzatok részleges vagy teljes „kivezetésének” problémájával. Ami természetesen nem jelenti minden, illetve más közösségi formák negligálását, sőt, éppenséggel esetleg azok kompenzációs előtérbe kerülése lehetőségként merül fel.

A puszta intézményi átrendezés ehhez édeskevés. Pénzügyi szabályozással a folyamat tisztázása érdekében többet lehet tenni. Például elkerülhető, hogy csak szervezeti megoldások merüljenek fel, ami a feladatellátás megmerevítéséhez vezethetne. Azonban az ilyen komplex újraértelmezési gyakorlatban oszlopos szerepet vállaló finanszírozási rendszer alakításának elemei nem „settenkedhetnek be” az éves költségvetési törvények eldugott részletszabályai közé. Már csak azért sem, mert akkor hoszszabb távú, szélesebb körben elfogadott koncepció elemeként nem lehetne őket komolyan venni. Az allokáció a nagy ellátó rendszerekben jelentős társadalompolitikai döntés. Ennek meghozatalához stratégia és alkalmazott stratégiai eszközök kellenek, amelyek nélkül még egy éppen eltalált jó szabály sem ér semmit. Söt, megfelelö környezet híján, gyakran többet árt, mint használ. A közfinanszírozás kereteinek illeszkedniük kell a társadalompolitikai célkitüzésekhez. Az önkormányzati intézményrendszer alakítását pedig az államháztartási reformokkal összefüggésben szabadna csak kezelni ${ }^{15}$. Egyben a reformkoncepciók helyi-területi vonzatait is komplexen fel kellene vetni.

\section{Jegyzetek}

${ }^{1}$ A cikk az Önkormányzati Obszervatórium Kht. számára írott, A forrásszabályozás kapcsolata az önkormányzati feladatrendszerrel címủ tanulmány (2007) részletének felhasználásával készült.

2 A kormányzati szintek közötti pénzügyi döntések elmélete a közpénzügyek körében. (Alkalmazására és áttekintésére lásd különösen Péteri [1992]; Capková [2000]; Horváth M. [2000]; Szalai [2002] tanulmányait!)

${ }^{3}$ A pénzügyi föderalizmusnak lényegét tekintve nincs sok köze a föderalizmushoz, mint államszerkezethez. Alapvetöen egységesen minden kormányzati szintre és szintközi viszonyra vonatkozik.

4 Távolabbi hipotézisünk a következỏ: lehetséges-e a szabályozást alapvetően a közfeladatok ellátási egységszintjeire méretezni és ehhez képest csak kiegészítölegesen még a politikai intézmények területi keretére - és nem pedig fordítva, miként az például a hazai önkormányzati finanszírozásban jellemzően történni szokott? 
${ }^{5}$ Minden finanszírozási reform mélyebb értelmében összefügg a feladatreformmal. Vigvári András írja, hogy itt amolyan tyúk-tojás problémáról van szó (Vigvári 2006, 239).

${ }^{6}$ L. erröl áttekintőlegesen Breuss-Eller (2003) tanulmányát!

${ }^{7}$ Talán pontosabb volna a továbbiakban a fogalmat „pénzügyi decentralizációnak” nevezni. A föderalizmusra való utalás azonban kifejezi, hogy nem elsősorban a döntéshozatali folyamatról van szó. A ,pénzügyi” jelző miatt pedig azért kell magyarázkodni, mert az angol megfelelő, fiscal federalism, szó szerinti jelenésében „, fiskálist” takarna, pedig itt tágabb jelentéskơrröl van szó, nem csak a forráscsökkentésröl.

${ }^{8}$ Ilyennek tekintik például az oktatást (1. a téma összefoglalására: Varga 1998, 31-36).

${ }^{9}$ Stiglitz $(1988,214)$ példája szerint a méhész méhei pozitív gazdasági eredményt hoznak a szomszédos almáskert tulajdonosának azzal, hogy beporozzák a virágokat. Tekintsünk most el attól, hogy a pozitív hatás itt kölcsönös (a méhész is nyer, költség nélkül), ami viszont a public choice elméletek egyik kedvelt kiindulópontja (Cullis-Jones 2003, 51-54).

${ }^{10} \mathrm{Az}$ internalizálás más formájára gyakran hivatkozzák Coase tételét, amely a tulajdonjogok definiảlásával teremt egyensúlyt az elönyök élvezöi és a károk elszenvedöi között, amit a környezetgazdálkodásban gyakran alkalmaznak (l. és v.ö. Nemec 1999, 63). Coase-nál persze a kulcskérdés, hogy meddig oldódik meg a kérđés a magánviszonyok közepette, és mikortól jut esetleg szerephez a közszektor, azaz a tranzakciós költségek hogyan alakulnak (Coase 1960).

11 A probléma tágabb összefüggésben való kifejtésére az önkormányzati rendszer vonatkozásában 1. a szerzőtől a következỏ cikket: Horváth M. 2005.

12 A táblázat egyes elemei és részstruktúrája Dafflon $(2006,301)$ mủvén alapulnak, bár eltérỏ cím és logika, továbbá összességében eltéró értelmezés szerint V.ö. a különböző tartalmakat!

${ }^{13}$ Pl. Nagy-Britannia alapszintü körzeti (district) önkormányzatai.

${ }^{14}$ Pl. régiók Lengyelországban (Regulski 2003), valamint Dánia új régiói (az utóbbiak alapja a kórházi ellátás területi körzete [1. erről Péteri 2006]).

15 Természetesen a szerzó tudja, hogy a mai politikai konstellációtól az ilyesfajta komplexitás nem várható el. A kétharmados megegyezésre képtelenség gátat szabna minden valódi kísérletnek. Másrészt az esetlegesen ellenható folyamatban az ơnjelölt reformerek ellenérdekeltsége is elég nyilvánvaló, immár sok év távlatából. Az efféle ,realitásokat" azonban - az elméleti összefuiggések pontosabb megvilágitása érdekében - ebben a tanulmányban szánt szándékkal nem vettük figyelembe.

\section{Irodalom}

Ahmed, E.-Giorgo, B. (eds.) (2006) Handbook of Fiscal Federalism. Edward Elgar, Cheltenham.

Bailey, S.J. (1999) Local Government Economics: Principles and Practice. MACMILLAN, Houndmills.

Bardhan, P. (2006) Decentralization and development. - Ahmad and Brosio. 201-223. o.

Batina, R.G -Toshihiro, I. (2005) Public Goods: Theories and Evidence. Springer Berlin.

Bird, R.M.- Ebel, RD.- Wallich, Ch. (1995) Fiscal decentralization: From command to market. - Bird, R.M.Wallich, Ch. (eds.) Decentralization of the Socialist State. Intergovernmental finance in Transition Economies. The World Bank, Washington. 1-67. o.

BM (2006) Tizenöt év a magyar önkormányzati rendszer szolgálatában. Önkormányzati tükör, 1990-2005. CD melléklet.

Breuss, F.-Eller, M. (2003) 'Efficiency and Federalism int he European Umion: The Optimal Assignment of Policy Taks to Different Levels of Government'. - Working Papers. IEF Working Paper Nr. 50. Research Institute for European Affairs, Wien.

Capková, S. (2000) Helyi kormányzati ügyek. - Nemec, J.-Wright, G. (szerk.) Közösségi pénzügyek. Aula, Budapest. 469-501. o.

Coase, R.H. (1960) 'The Problem of Social Cost'. - Journal of Law and Economics. 3. 1-44.

Cullis, J.-Jones, P. (2003) Közpénzügyek és közösségi döntések. Aula, Budapest:

Dafflon, B. (2006) The assignment of functions to decentralized government: from theory to practice. Ahmad and Brosio. 271-305. 0.

Davey, K.-Horváth M.T.-Péteri G. (2000) Jelentés. - Helyi önállóság és önkormányzati feladatok. Tanulmányok. - Közigazgatás-fejlesztési füzetek 1. Miniszterelnöki Hivatal Közigazgatás- és Területpolitikai Államtitkárság, Budapest. 
Horváth M.T. (2000) Közösségi pénzügyek a politikai rendszerekben. - Nemec, J.-Wright, G. (szerk.) Közösségi pénzügyek. Aula, Budapest. 112-143. o.

Horváth M.T. (2002) Helyi közszolgáltatások szervezése. Dialóg Campus, Budapest.

Horváth M.T. (2005) MINTHA-KöVETÉS. Globalizációs problémák az önkormányzati fejlödés példáján. www.jogimuhely.hu 3.

King, D. (1984) Fiscal Tiers: The Economics of Multi-Level Government. George Allen \& Unwin, London.

Lockwood, B. (2006) The political economy of decentralization. - Ahmad and Brosio. 33-60. o.

Musgrave, R.A. (1959) The Theory of Public Finance. McGraw-Hill, New York.

Musgrave, R.A.-Musgrave, P.B. (1989) Public Finance in Theory and Practice. McGraw-Hill, New York.

Nemec, J. (1999) 'Economic and Social Basis for Government Actions'. - Nemec, J.-Wright, G. (szerk.) Közösségi pénzügyek. Aula, Budapest. 55-97. 0.

Nemec, J.-Glen, W. (1999) (eds.) Public Funance: Theory and Practice in the Central European Transition. NISPAcee, Bratislava.

Oates, W.E. (1972) Fiscal Federalism. Harcourt Brace Jovanovich, New York.

Olson, M. (1969) 'The principle of „fiscal equivalence": the division of responsibilities among different levels of government.' - American Economic Review. 59. 479-487. o.

Péteri G. (1992) Költségvetési szociológia, „Helyi demokrácia és újítások” Alapítvány, Budapest.

Péteri G. (2006) Hogyan csináljunk közigazgatási reformot? Dániai tanulságok Magyarország számára. -

Vigvári A. (szerk) Decentralizáció, transzparencia, elszámoltathatóság. MKI, Budapest. $11-44$. o.

Regulski, J. (2003) Local Government Reform in Poland: An Insider's Story. OSI/LGI, Budapest.

Shah, A. (1994) The Reform of Intergovernmental Fiscal Relations in Developing and Emerging Market Economies. - Policy and Research Series. 23. The World Bank, Washington.

Stiglitz, J.E. (1988) Economics of the Public Sector. Norton, New York.

Swianiewicz, P. (2003) Foundation of Fiscal Decentralization: Benchmarking Guide for Countries in Transition. - Discussion Papers. 26. Local Government and Public Service Reform Initiative. Open Society Institute, Budapest.

Szalai Å. (2002) Fiskális föderalizmus. Áttekintés. - Közgazdasági Szemle. Május. 424 440. o.

Tiebout, Ch.M. (1956) „A Pure Theory of Local Expenditures”. - The Journal of Political Economy. 5. 416-424. o.

Tiebout, Ch.M. (1961) 'An economic theory of decentralization' in NBER. - Public Finance, Needs, Sources and Utilization. Princeton University, Princeton.

Varga J. (1998) Oktatás-gazdaságtan. Kỏzgazdasági Szemle Alapitvány, Budapest.

Vigvári A.(2005) Közpénzügyeink. KJK-KERSZÖV, Budapest.

Vigvári A. (2006) Finanszirozási reform vs. feladattelepités. Néhány szempont az ơnkormányzati rendszer reformjához. - Magyar Közigazgatás. 3-4. 232-247. o.

\section{URBAN MANAGEMENT AND FISCAL FEDERALISM}

\section{TAMÁS HORVÁTH M.}

The definition of town has become relative in the last two decades, principally because of changing policy of legal status of settlements. Therefore the urbanized management is independent from the administrative status. In Hungary the laws on local government establish their structure of regulation (mostly) on operation of settlements and (less) of voted and official bodies by the counties. On the other hand the fiscal federalism focuses on the interactions between the system elements.

In line with coming to the fore of evaluation of budget functions the self government subsystem should be defined rather as dynamic than static. Also it is needed to think in terms of function units instead fundamental units. These might be citied and urbanization functions which could be created or inspired by direct regulation.

In this context the democratic elements could not be separated from aspects of effectiveness and even more of social efficiency (regional/territory), also from harmonised framing of distributional systems. 